\title{
Sobre as relações dialéticas entre história e literatura
}

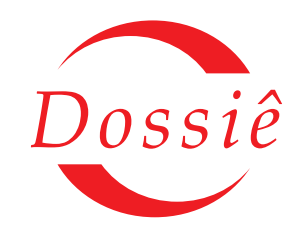

Os textos que o leitor tem em mãos neste dossiê partem de um pressuposto comum: a literatura é um documento do seu tempo e do seu lugar. Soa tautológico quando historiadores sugerem que um documento histórico deve ser compreendido como parte inseparável do seu contexto, como resultado dos embates sociais, políticos, culturais e econômicos do seu tempo, do seu lugar; e, simultaneamente, produto e produtor desse contexto. Mas é preciso dizê-lo novamente, e provavelmente ainda será necessário dizê-lo outras vezes, porque tomar a literatura como produto do seu tempo e lugar, como documento histórico, tem sido um pressuposto que tem afastado, de modo inconciliável, os historiadores dos críticos literários. Não de todos os críticos literários, por óbvio, mas sobretudo daqueles que insistem em atribuir à literatura um lugar especial, reservando a ela o lugar mais elevado da imaginação, da criação, da fantasia, da liberdade. Nos artigos reunidos nesta coletânea, ao contrário, a literatura é um produto material, tão material quanto pregos e parafusos, exatamente por isso, um produto do mundo, do contexto, dos conflitos que o formam e informam.

Como historiadores sociais, podemos concluir que os que tomam a literatura como instalada num mundo à parte, nas altas esferas da imaginação, não estão de todo equivocados. Afinal, desde os fins do século XVIII é assim que o mundo capitalista tem sido configurado, separando cuidadosamente as atividades do pensamento e da imaginação - às quais se atribui qualidade, valor, sofisticação e enlevo, sempre ao alcance de poucos - das atividades meramente manuais, relegadas ao reino das necessidades, da praticidade, da reprodução da vida, sem nenhum destaque ou importância especial, já que ao alcance de todos como simples instinto. De um lado, o espírito e todos os atributos do deslumbramento, do arrebatamento, dos recônditos da alma; de outro, as habilidades manuais, a destreza, aprendidas com treino e dedicação, mas das quais não se exige nada além da repetição. Esse princípio da separação entre corpo e espírito, fundamental para a constituição da sociedade capitalista moderna, para a divisão do trabalho que a modela e para a alienação capitalista que nos informa e deforma a todos, é central também na consolidação das hierarquias de raça e de gênero, ao atribuir superioridade aos que operam as ideias sobre os que operam as ferramentas, aos que se apresentam no mundo público sobre os que são restringidos ao mundo privado, por ignorância, despreparo ou infantilidade.

Portanto, os autores deste dossiê recusam essa separação corpo/espírito e tomam a literatura como material e historicamente determinada. Mas isso não os faz ingênuos, ou simples "sociólogos da cultura", como muitos de nós já ouvimos; sabemos que a literatura resulta do seu meio e do seu lugar, porém tem uma peculiaridade, em relação a outros documentos históri- 
cos, porque continua sendo lida, interpretada e produzindo efeitos sensíveis em tempos distintos daquele em que foi produzida (muito diferente de outros documentos históricos como uma matéria de jornal, uma ata de associação, um relato policial). Assim, a literatura tem a capacidade, porque lida com experiências humanas, de dizer sobre os homens e mulheres o que lhes é particularmente humano, o que os recoloca diante de experiências humanas de outros tempos, de soluções outras, de conflitos distintos, como sugeriu Karl Marx. E parafraseando um grande sábio: nós somos como o ogro da lenda; ali onde farejamos carne humana está a nossa caça.

Sabemos também que a literatura não se relaciona apenas com o seu tempo e o seu lugar. Ela se relaciona consigo própria. Dito de outro modo, as obras literárias se relacionam com outras obras literárias com as quais mantêm direto ou indireto diálogo, relacionam-se também com os críticos literários, com os editores, com os tradutores, com o público consumidor; enfim, com aquilo que já se definiu como campo literário. Desse modo, nem sempre é suficiente desvendar o contexto histórico-social de produção de uma obra. É preciso investigar sua relação com outras obras, do mesmo tempo, ou de tempos pretéritos, a relação dos autores com seus editores, com seus tradutores, com os meios de comunicação em geral, com as instituições de consagração, na forma de premiações, prebendas, vantagens etc.

Seria, por fim, desnecessário destacar que estamos em face de estudos que nos apresentam um exemplo rico do que temos aqui chamado, com certa insistência, de dialética entre literatura e história.

Adriano Duarte e Denilson Botelho Organizadores do dossiê 